\title{
ANTIBACTERIAL EFFECTS OF SARANG SEMUT (MYRMECODIA PENDANS) FRACTIONS USING THREE DIFFERENT SOLVENTS TOWARD ENTEROCOCCUS FAECALIS CPS2
}

\author{
CIPTADHI TRI OKA BINARTHA ${ }^{1}$, ENDANG SUPRASTIWI'* ${ }^{2}$, DIDIK KURNIA ${ }^{3}$, ANGGRAINI MARGONO ${ }^{2}$, \\ DEWA AYU NYOMAN PUTRI ARTININGSIH ${ }^{2}$
}

${ }^{1}$ Doctoral Program, Faculty of Dentistry, Universitas Indonesia, Jakarta, Indonesia. ${ }^{2}$ Department Conservative Dentistry, Faculty of Dentistry, Universitas Indonesia, Jakarta, Indonesia. ${ }^{3}$ Department of Chemistry, Faculty of Mathematics and Natural Sciences, Universitas Padjadjaran, Bandung, Indonesia. Email: esuprastiwi@yahoo.co.id

Received: 27 November 2019, Revised and Accepted: 18 December 2019

ABSTRACT

Objective: This study investigated the effect of antibacterial activity from sarang semut fractions with three different solvents, i.e. nonpolar (n-hexane), semipolar (ethyl acetate), and polar (water), to determine the minimum inhibitory concentration (MIC) on Enterococcus faecalis cps2.

Methods: The fractions were extracted with a maceration method and a methanol solvent. The fractionation was performed with three groups of solvent to obtain the n-hexane, ethyl acetate, and water fractions. The active compound from the best fraction group was identified using a phytochemical test, gas chromatography-mass spectrophotometry, and thin-layer chromatography. Each fraction group was divided into five different concentrations, i.e. $20 \%, 40 \%, 60 \%, 80 \%$, and $100 \%$ and was assessed against E. faecalis cps 2 with an agar diffusion method. Chlorhexidine $2 \%$ was used as a positive control. The width of the inhibition zone was calculated.

Results: The ethyl acetate group had the biggest inhibition zone of $21 \mathrm{~mm}$ in diameter compared to n-hexane and water, which was $15 \mathrm{~mm}$ and $19 \mathrm{~mm}$ in diameter, respectively. The MIC value of the fraction with a $20 \%$ concentration of ethyl acetate was significantly different (P< 0.05 ) from the $\mathrm{n}$-hexane and water solvents in inhibiting the growth of E. faecalis cps2.

Conclusion: The ethyl acetate fraction of sarang semut had a greater inhibitory effect on E. faecalis cps2. In addition, the antibacterial activity of the fraction increased with an increase in concentration.

Keywords: Fraction, Sarang semut, n-hexane, Ethyl acetate, Water, Enterococcus faecalis, cps2, Minimum inhibitory concentration.

(c) 2020 The Authors. Published by Innovare Academic Sciences Pvt Ltd. This is an open access article under the CC BY license (http://creativecommons. org/licenses/by/4. 0/) DOI: http://dx.doi.org/10.22159/ijap.2020.v12s1.iwdr01

\section{INTRODUCTION}

Medicinal herbs were used as the primary health-care agents over many centuries before the dawn of modern medicine. Sarang semut (Myrmecodia pendans) is a plant from Indonesia that has been empirically demonstrated to cure various diseases such as heart disease, cancer, hemorrhoids, stomach ulcers, tuberculosis, rheumatism, stroke, kidney function disorders, and prostate gland problems. In addition, water-boiled sarang semut can also facilitate breast milk expression, can heal menstruation dysfunctions, and can overcome vaginal discharge problems in women [1]. Some researchers have suggested that sarang semut has anticancer activity against squamous cell-type cancer by inhibiting SP-C1, MCM-B2, and HeLa cancer cell proliferation. It is also said to have antibacterial activity against Escherichia coli. Sarang semut plant extracts can also inhibit xanthine oxidase enzyme activity in increasing uric acid production, which can cause joint pain and inflammation. Sarang semut plants contain antioxidants, namely, procyanidin B1, rosmarinic acid, and procyanidin polymer B1 [1-4]. In addition, sarang semut tubers contain bioactive compounds, mostly from the tannins and flavonoids possessing the ability to cure various diseases. In addition, it contains active compounds of alkaloids, terpenoids, and phenolics, which possesses antifungal, anticancer, and antibacterial bioactivities $[5,6]$.

The choice of solvent is a very important factor because extracts of chemical compounds from plants can play a role in biological activity. Organic solvents and water facilitate the extraction of all compounds that were soluble in both organic solvent and water. The solvent effects are related to polarity, which is an organic reaction. The solvent acts as a medium to facilitate mixing, stabilizing the reactions that occur, regulating the temperature, and helping in the transfer of protons. The selection of the appropriate solvent is very helpful for the success of a reaction. There are three types of solvents, namely, nonpolar, semipolar, and polar [7-10].

One of the pathogenic bacteria that cause infection is Enterococcus faecalis, which is a normal flora in the digestive and urinary tract of women. It is also found in the oral cavity, where it is an opportunistic bacteria capable of forming biofilms [11]. E. faecalis in the oral cavity is found in the root canals of teeth, especially when there is a failure of endodontic treatment [12]. The virulence factors of E. faecalis include adhesin (aggregation substance, Esp/surface protein/Esp, collagen adhesion protein/Ace, and antigen A/EfaA), cytolysin and proteolytic enzymes (gelatinase and serine protease), and capsular polysaccharide (cps) [13]. E. faecalis has several types of capsules; one of them is based on the type of antigen in the polysaccharide capsule [14]. Polysaccharide capsules can also be used to identify E. faecalis genotypes by considering the type of capsule. E. faecalis polysaccharide capsules have 11 different variations, namely, cpsA-cpsK. Only seven groups of E. faecalis capsules have been identified, i.e. cpsC, cpsD, cpsE, cpsG, cpsI, cpsJ, and cpsK [15]. Genetically, the synthesis of polysaccharide capsule operon coding and a polymorphism locus was found in the clinical isolates of E. faecalis [16-18]. E. faecalis cps2 is the major bacterial strain that has been implicated in root canal persistent intraradicular infection relative to cps1 and cps5 strains. E. faecalis cps2 is comparatively common in Indonesians who require root canal treatment [19].

Polysaccharide capsules act as important virulence factors expressed by bacteria. This is due to the polysaccharide capsule being able to 
protect bacteria from the host's immune system, which can make the infection persist longer. Bacterial strains that produce capsules are more resistant than bacteria that do not have capsules $[14,20]$. According to Pinheiro et al. (2012), the identification of E. faecalis from 22 root canals indicated that most $E$. faecalis bacteria do not have polysaccharide capsules; these are called genotype cps1. The remainder, however, express polysaccharide capsules; they are called genotypes cps2 and cps5 [15]. An antibacterial effect may be the result of an active compound, such as polyphenol, and its secondary metabolites, such as tannins and flavonoids, in sarang semut [21]. These compounds play an important role in antibacterial activities and also protect against toxins and free radicals $[22,23]$. In flavonoids, there are many antibacterial mechanisms that have been discovered. For example, flavonoids can interact with cell wall bacteria to damage the integrity of the cell wall structure and can cause cell death [22].

The success of root canal treatment requires the removal of irritants such as microorganisms, necrotic tissues, and microbial byproducts from the root canal system, and preventing reinfection is necessary [24]. This goal can be achieved using chemical and mechanical processes. Chemical solutions for irrigation play a central role in root canal treatment. One of the requirements for irrigation solutions is they need to have antimicrobial activity [25]. Synthetic medicine not only cure diseases but also have side effects in the human body [26]. Several irrigating solutions, such as chlorhexidine, have common side effects, which have a cytotoxic potential that can cause severe pain if they remain in the periapical tissues. Other problems include tooth discoloration, mouth ulcers, and allergic reactions [27]. The requirements for any medicine are it must be nontoxic, it must be effective, and it must have specificity, potency, and stability. Herbal medicine can be used to cure many ailments and can also reduce side effects [26].

There are many studies that have evaluated traditional irrigants, especially irrigants that can replace chlorhexidine. Hopefully, this study can identify a new irrigant solution that can be used in future root canal treatments and can also elucidate their advantages and limitations. In previous studies, different solvent extracts showed differential potency against the tested bacterial species [21]. This study aimed to determine the best solvent for the extraction of active compounds that are responsible for antibacterial effects. The effects of three solvents, namely, n-hexane (nonpolar), ethyl acetate (semipolar), and water (polar), of sarang semut tubers extract (Myrmecodia pendans) were tested to assess their efficacy in inhibiting the growth of $E$. faecalis cps2.

\section{METHODS}

The extract was made from sarang semut tubers obtained from the Papua region, and the fractions were extracted using a maceration method with the methanol solvent. The fractionation was performed using three groups of solvents (n-hexane, ethyl acetate, and water) to obtain the n-hexane, ethyl acetate, and water fractions. The concentrations of the extracts were $20 \%, 40 \%, 60 \%, 80 \%$, and $100 \%$. We used $100 \%$ to determine whether each concentration of the fraction was suitable for an antimicrobial assay. The extra solvent was evaporated with a rotary evaporator, and a final concentration of $250 \mathrm{mg} / \mathrm{mL}$ was achieved. The active compounds of the sarang semut fraction were analyzed with a phytochemical test, gas chromatography-mass spectrophotometry (GC-MS), and thin-layer chromatography (TLC).

E. faecalis cps2 bacteria were obtained from the University of Indonesia's Oral Biology Laboratory of Faculty of Dentistry. E. faecalis cps2 was cultured into $35 \mathrm{~mL}$ of sterile brain heart infusion (BHI) broth (SigmaAldrich; BCBT4222) and was incubated at $37^{\circ} \mathrm{C}$ for $24 \mathrm{~h}$. Furthermore, according to the recommended standardization bacterial culture for a minimum inhibitory concentration (MIC) method, bacterial dilution was carried out to a 0.5 McFarland turbidity standard, which was calculated using a microplate reader.

A total of $37 \mathrm{~g}$ of $\mathrm{BHI}$ was dissolved into $1 \mathrm{~L}$ of distilled water and then poured into 50 Petri dishes and left to stand at room temperature. This was followed by storage in a refrigerator at a temperature of $4^{\circ} \mathrm{C}$. A total of $100 \mu \mathrm{L}$ of E. faecalis cps 2 culture was inoculated on the surface of BHI agar using spreaders. The Petri dishes were then incubated for 24 $\mathrm{h}$ at $37^{\circ} \mathrm{C}$. Each plate containing the BHI agar medium was perforated 6 times at different regions using a perforator.

The sarang semut plant extract was divided into three groups of fractions. The first fraction group was n-hexane, the second fraction group was ethyl acetate, and the third fraction group was water. Each sarang semut fraction group was divided into five different concentrations $(20 \%$, $40 \%, 60 \%, 80 \%$, and $100 \%$ ). A total of $50 \mu \mathrm{L}$ of each concentration was inserted into a well. Chlorhexidine digluconate (CHX) $2 \%$ was used as a positive control, and BHI was used as a negative control in this study.

Table 1: The mean value and significance of the inhibitory zone ( $\mathrm{mm})$ in each solvent group

\begin{tabular}{|c|c|c|c|c|c|c|}
\hline \multirow[t]{2}{*}{ No } & \multirow[t]{2}{*}{ Concentration (\%) } & \multicolumn{3}{|c|}{ Inhibitory zone (mm) and type of solvent } & \multirow[t]{2}{*}{ CHX 2\% } & \multirow[t]{2}{*}{ Sig. } \\
\hline & & n-hexane & Ethyl acetate & Water & & \\
\hline 1 & 100 & 15 & 21 & 19 & & $0.001^{*}$ \\
\hline 3 & 60 & 9 & 20 & 15 & & \\
\hline 4 & 40 & 10 & 20 & 11 & & \\
\hline 5 & 20 & 8 & 15 & 10 & & \\
\hline 6 & $\mathrm{CHX} 2$ & & & & 21 & \\
\hline
\end{tabular}

CHX: Chlorhexidine digluconate

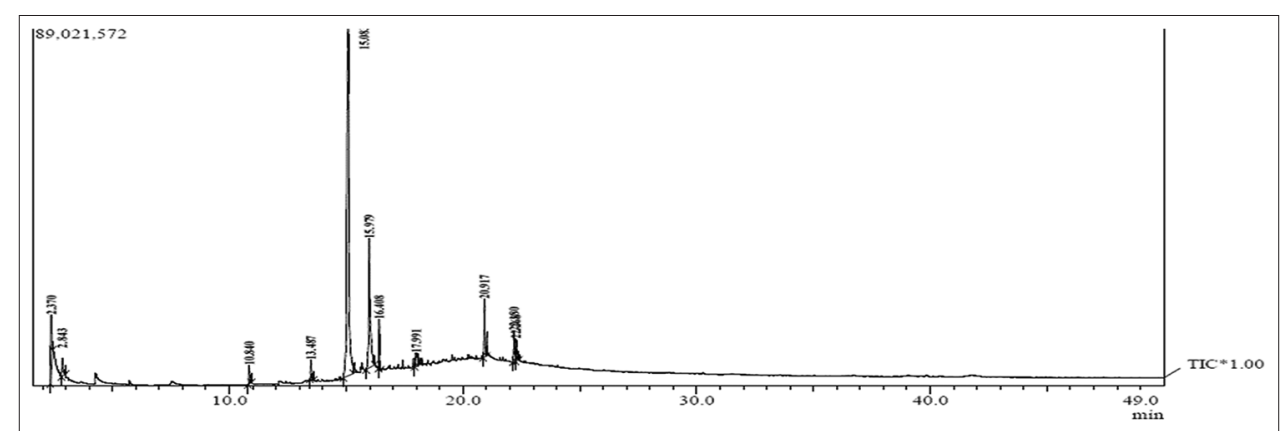

Fig. 1: Gas chromatography-mass spectrophotometry chromatogram of the ethyl acetate fraction of sarang semut 
The experiment was repeated $2 \times$ (duplo) for each concentration. The plate was placed into an incubator at $37^{\circ} \mathrm{C}$ for $24 \mathrm{~h}$. The experiments were performed by a single experimental unit and replicated per group in duplicate (duplo). The MIC was calculated by measuring the width of the inhibitory zone, which was seen as the area where there was no bacterial growth around the well.

\section{RESULTS AND DISCUSSION}

\section{Results}

The inhibitory zone diameter results of the sarang semut fractions showed that the ethyl acetate fraction had a larger inhibition zone diameter than the $n$-hexane and water fractions. The obtained data were analyzed using IBM devices SPSS version 20 by performing an ANOVA (Table 1 ).

The largest inhibitory zone belonged to the $100 \%$ ethyl acetate fraction $(21 \mathrm{~mm})$, while the smallest belonged to the $20 \%(8 \mathrm{~mm}) \mathrm{n}$-hexane fraction group. The ethyl acetate fractions had the largest inhibitory zones with CHX ( $21 \mathrm{~mm}$ ) as compared to $\mathrm{n}$-hexane and water fractions. The results of a statistical analysis using an ANOVA show that there were significant differences between the effects of three groups of fractions on the growth of E. faecalis cps2. The inhibitory zone of the ethyl acetate fraction showed more stable values between concentrations when compared to $\mathrm{n}$-hexane and water fractions.

The screening test of the active compounds by phytochemical test, GC-MS, and TLC on the ethyl acetate fraction of sarang semut showed positive results of several active compounds.

Phytochemical components have been analyzed qualitatively, and they showed several percentages of the active compound saponin, tannin, phenolic, flavonoid, alkaloid, triterpenoid, and glycoside (Table 2).

The peak in the GC-MS chromatogram of the ethyl acetate fraction of sarang semut showed the presence of the secondary phytochemical compounds such as phenolic and fatty acid (Fig. 1).

Table 2: Phytochemical test of the ethyl acetate fraction of sarang semut

\begin{tabular}{lll}
\hline Fraction & Compound & Result \\
\hline Ethyl acetate fraction of sarang semut & Saponin & + \\
& Tannin & + \\
& Phenolic & + \\
& Flavonoid & + \\
& Alkaloid & + \\
& Triterpenoid & + \\
& Steroid & - \\
& Glycoside & + \\
\hline
\end{tabular}

$(+)$ contained; $(-)$ not contained
Eleven peaks were obtained, and all the phytocomponents were identified and characterized (Table 1). The retention times (RTs) are in minutes. The components were grouped into the main classes: Flavonoid $(60.05 \%)$, phenolic $(20.17 \%)$, organic compound $(11.39 \%)$, and fatty acid (9.38\%) (Table 3). The peak area, RT, molecular formula, and molecular weight were used to confirm the phytochemical components of the fraction.

TLC, which is used for the separation of several compounds, was used to analyze the inside of the sarang semut fraction.

The solvent system was made from n-hexane-ethyl acetate $1: 4(\mathrm{v} / \mathrm{v})$ and n-hexane-ethyl acetate 7:3 (v/v). $\mathrm{H}_{2} \mathrm{SO}_{4}$ spray was used to detect the spot chemical compound. The TLC plate with $\mathrm{H}_{2} \mathrm{SO}_{4}$ spray is colorless under daylight but is colored under ultraviolet (UV) light. The TLC after viewing under UV light and Rf value was calculated. The sarang semut fraction showed several spots of red, yellow, light blue, and dark brown color. Three spots of the yellow fraction 8-10 had Rf values of $0.40,0.55$, and 0.55 , respectively. The dark brown fraction 11-13 had Rf values of 0.38 and 0.43 (Fig. 2). Columns 4-7 had red and light blue with Rf values of $0.30,0.23$, and 0.07 respectively (Fig. 3 ).

\section{DISCUSSION}

The polarity of a solvent greatly influences the solubility of a compound. The indicator of the solute is determined by the polarity of the solvent and the dielectric constant. These two things are related to each other. The value of solvents with solutes is the total solubility value. If the solubility value has almost the same value, then the compound will be easier to dissolve. The total solubility parameters include polar, nonpolar, and hydrogen bonds [28]. This study also used a method that searched for solvents according to the total solubility parameters based on the polarity of solvents, such as n-hexane (polar), ethyl acetate (semipolar), and water (polar).

The antibacterial activity of plants has been studied using different solvents. The findings showed that different solvents have various active compounds based on their phytochemical content and antibacterial effects. The water extract has the potential effect of inhibiting Bacillus subtilis and Staphylococcus aureus [29,30]. Ehsan et al. reported that methanol and ethanol extracts of Hopea parviflora Beddome had antibacterial activity against $S$. aureus [31]. Bakht et al. investigated the antibacterial activities of different solvents of ethyl acetate, butanol, $\mathrm{n}$-hexane, and distilled water against seven bacterial and one fungal pathogen. From that result, ethyl acetate and butanol reduced the growth of Bacillus cereus [32]. Fatriadi et al. stated that the ethyl acetate fraction of sarang semut had antibacterial activity against Streptococcus sanguinis. Kurnia et al. investigated the ethyl acetate fraction of sarang semut toward Porphyromonas gingivalis [33,34].

Table 3: GC-MS analysis of the ethyl acetate fraction of sarang semut

\begin{tabular}{|c|c|c|c|c|c|c|}
\hline No & Retention time & $\%$ concentration & Name of the compound & $\begin{array}{l}\text { Molecular } \\
\text { formula }\end{array}$ & $\begin{array}{l}\text { Molecular } \\
\text { weight }(\mathrm{g} / \mathrm{mol})\end{array}$ & $\begin{array}{l}\text { Natural } \\
\text { compound }\end{array}$ \\
\hline 1 & 2.37 & 5.81 & Formamide (CAS) methanamide & $\mathrm{CH}_{3} \mathrm{NO}$ & 45.04 & Organic \\
\hline 2 & 2.843 & 1.91 & 2-Propanone (CAS) acetone & $\mathrm{C}_{2} \mathrm{H}_{6} \mathrm{O}$ & 58.08 & Organic \\
\hline 3 & 10.84 & 1.35 & 2(5H)-FURANONE & $\mathrm{C}_{4}^{3} \mathrm{H}_{4}^{6} \mathrm{O}_{2}$ & 84.07 & Organic \\
\hline 4 & 13.487 & 1.69 & Phenol, 2-methoxy- (CAS) guaiacol & $\mathrm{C}_{7} \mathrm{H}_{8} \mathrm{O}_{2}$ & 124.14 & Phenolic \\
\hline 5 & 15.083 & 60.05 & $\begin{array}{l}\text { Benzene, p-di-tert-butoxy- (CAS) 1,4-DI-TERT- } \\
\text { BUTOXYBENZENE }\end{array}$ & $\mathrm{C}_{14} \mathrm{H}_{22} \mathrm{O}_{2}$ & 190.32 & $\begin{array}{l}\text { Flavonoid } \\
\text { phenolic }\end{array}$ \\
\hline 6 & 15.979 & 16.22 & 4-METHYLCATECHOL & $\mathrm{C}_{7} \mathrm{H}_{8} \mathrm{O}_{2}$ & 124.13 & Phenolic \\
\hline 7 & 16.408 & 2.28 & Phenol, 2,6-dimethoxy- (CAS) 2,6-Dimethoxyphenol & $\mathrm{C}_{8} \mathrm{H}_{10} \mathrm{O}_{3}$ & 154.16 & Phenolic \\
\hline 8 & 17.991 & 2.32 & $\begin{array}{l}\text { 1,6-ANHYDRO-BETA-D-GLUCOPYRANOSE } \\
\text { (LEVOGLUCOSAN) }\end{array}$ & $\mathrm{C}_{6}^{8} \mathrm{H}_{10} \mathrm{O}_{5}^{3}$ & 162.14 & Organic \\
\hline 9 & 20.317 & 3.74 & Hexadecanoic acid (CAS) palmitic acid & $\mathrm{C}_{16} \mathrm{H}_{30} \mathrm{O}_{2}$ & 256.43 & Fatty acid \\
\hline 10 & 22.18 & 3.52 & 9-Octadecenoic acid (Z)- (CAS) oleic acid & $\mathrm{C}_{16}^{16} \mathrm{H}_{22} \mathrm{O}_{2}$ & 282.47 & Fatty acid \\
\hline 11 & 22.268 & 2.12 & 9-Octadecenoic acid (Z)-, ethyl ester (CAS) ethyl oleate & $\mathrm{C}_{20}^{18} \mathrm{H}_{38}^{34} \mathrm{O}_{2}^{2}$ & 310.52 & Fatty acid \\
\hline
\end{tabular}




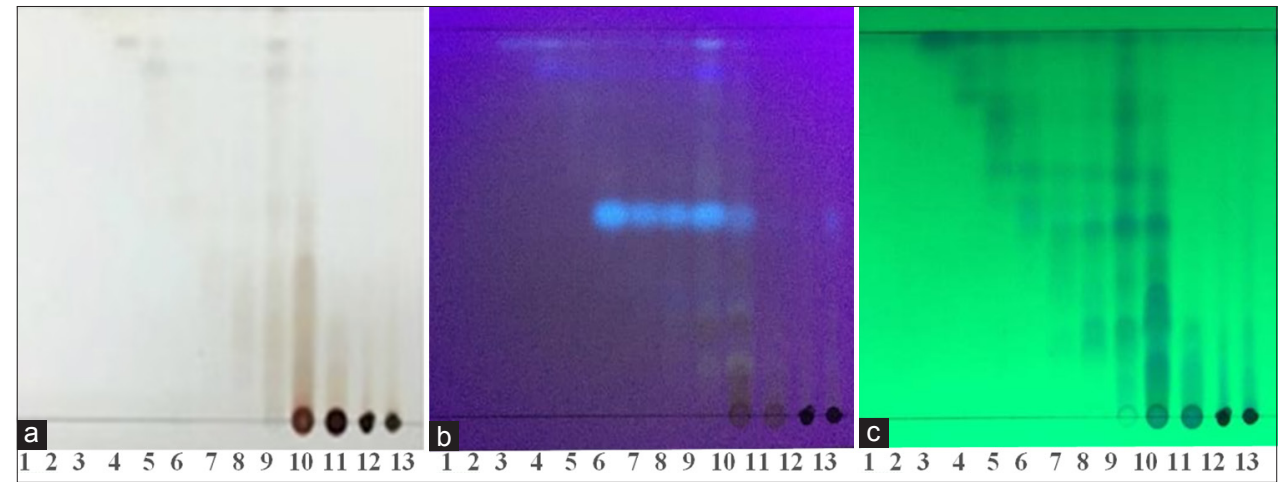

Fig. 2: Thin-layer chromatography fingerprints of the sarang semut fractions 1-13, solvent system $n$-hexane-ethyl acetate 1:4 (v/v), (a) $\mathrm{H}_{2} \mathrm{SO}_{4}$ spray, (b) under ultraviolet (UV) light $365 \mathrm{~nm}$, (c) under UV light $254 \mathrm{~nm}$

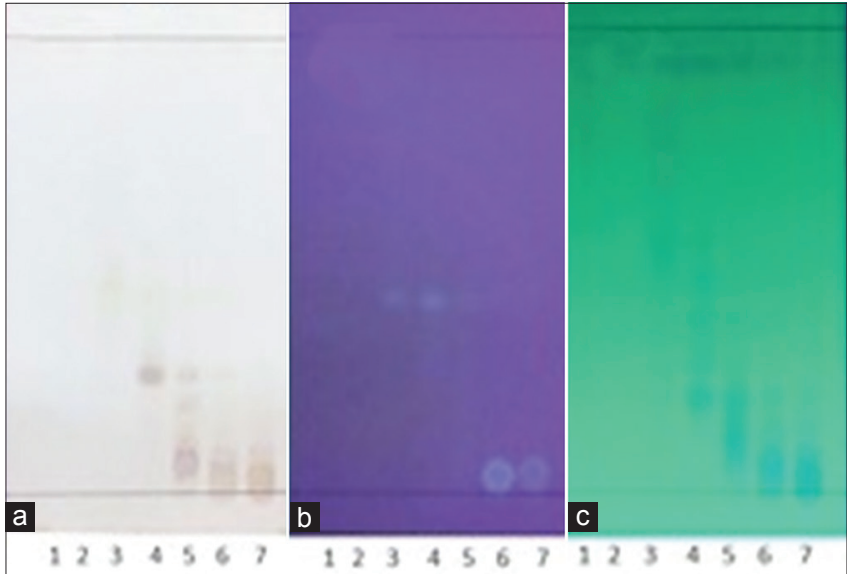

Fig. 3: Thin-layer chromatography fingerprint of the sarang semut fractions 1-7, solvent system n-hexane-ethyl acetate 7:3 (v/v), (a) $\mathrm{H}_{2} \mathrm{SO}_{4}$ spray, (b) under ultraviolet (UV) light $365 \mathrm{~nm}$, (c) under UV light $254 \mathrm{~nm}$

Sensitivity tests for $E$. faecalis cps2 bacteria were performed because these bacteria have capsules that possess higher resistance to antibiotics compared to bacteria that do not have capsules. The cps2 capsule type is the most common in endodontic cases of persistent infection in Indonesia [19]. The MIC method is used to examine the drug sensitivity of bacteria. The MIC method can be performed using an agar diffusion method using filter paper discs and wells. This diffusion method is a qualitative method that is simple, accurate, and reproducible $[35,36]$.

Based on the results of this study, the mean inhibition zone values of the ethyl acetate group at all concentrations had the highest values, which were then followed by the water group, and the lowest was the $\mathrm{n}$-hexane group (Table 1). The fraction using ethyl acetate had nontoxic, polar, non-hygroscopic, and volatile properties, which could dissolve compounds in sarang semut plant cell walls such as flavonoids [21,37]. Phenolic compounds can also damage the permeability of bacterial cell membranes by denaturing bacterial cell proteins, resulting in stunted cell growth or death [8]. Flavonoids in sarang semut plants can behave as antibiotics by interfering with the metabolic functions of viruses and bacteria. The mechanisms of antibacterial activity of flavonoid compounds include the inhibition of nucleic acid synthesis, disruption of bacterial cell membranes, and inhibition of bacterial cell energy formation [38]. Fig. 1 and Table 1 showed that a higher concentration of the sarang semut plant fraction meant there were higher inhibitory effects on the growth of E. faecalis cps2. This is caused by differences in the polarity of the solvent. Ethyl acetate is a polar solvent, and the main sarang semut plant fraction contains phenolic compounds. Polar solvents can dissolve phenolic compounds better than other solvents, resulting in higher levels of phenolic compounds in the fraction [39].
Therefore, compounds derived from natural ingredients are more easily dissolved in polar solvents.

Phytochemical analysis showed that the ethyl acetate fraction of sarang semut contains a mixture of active compounds, i.e., tannins, saponins, flavonoids, phenolics, triterpenoids, alkaloids, and glycoside (Table 2). According to Engida et al. (2013), sarang semut has phenolic and flavonoid compounds [21]. Many of the phytochemical compounds present in the entire sarang semut plant that was detected by GC-MS are shown in Table 3. The GC-MS analyses the eluted compound at different times to identify phytochemical compounds. Large compounds changing into small compounds give rise to visual peaks at different ratios, and the fingerprints of the detected compounds can be identified from the data library $[40,41]$. TLC was carried out using different types of solvent systems with varying polarity. TLCs are used to separate the secondary metabolites of plant extracts [37]. TLC profiling showed different Rf values. Different $\mathrm{Rf}$ values of the compound depend on their polarity, which can be useful for selecting particular solvents for further research [42]. These three different analyses have shown the presence of various phytochemical compounds in the ethyl acetate fraction of sarang semut.

The significance test of the n-hexane group showed that the n-hexane solvent was effective against $E$. faecalis cps2 at a concentration of $80 \%$ because the $n$-hexane solvent is a nonpolar solvent. Non-polar solvents have greater difficulty attracting compounds, such as phenols. In the ethyl acetate group, it was shown that the sarang semut fraction at a concentration of $20 \%$ was effective in inhibiting the growth of $E$ faecalis cps2 bacteria, whereas in the water solvent group, the effective concentration started at a concentration of $60 \%$. This was due to the nature of each solvent type. Unlike water, ethyl acetate is a volatile and flammable solvent, in which the vaporization process does not need heating. This heating process that is required in water vaporization can be the cause of differences in the number of active antibacterial compounds in a sarang semut fraction, so the inhibitory zones obtained are also different. These results indicated that the ethyl acetate solvent in the sarang semut fraction has a stronger antibacterial activity against the growth of E. faecalis cps2. This was also supported by several studies showing that TLC analysis of several bioactive compounds dissolved in ethyl acetate solvent gave better results than n-hexane, acetone, ethanol, and water solvents $[43,44]$.

\section{CONCLUSION}

Based on the results of this study, it can be concluded that among n-hexane, ethyl acetate, and water solvents, ethyl acetate is the best solvent for sarang semut plant fractions, because it has a more effective inhibitory effect on the growth of E. faecalis cps2. In addition, the antibacterial activity of the fraction increased with an increase in its concentration.

\section{CONFLICTS OF INTEREST}

The authors declare that there are no conflicts of interest. 


\section{REFERENCES}

1. Soeksmanto A, Subroto MA, Wijaya H, Simanjuntak P. Anticancer activity test for extracts of sarang semut plant (Myrmecodia pendens) to HeLa and MCM-B2 cells. Pak J Biol Sci 2010;13:148-51.

2. Simanjuntak PS. Isolation of active compounds from ants nest hypocotyl extract (Myrmecodia pendens Merr and Perry) as xantinoksidase inhibitors. J Ilmu Kefarmasian Indones 2010;8:49-54.

3. Achmad H, Supriatno S, Marhamah M, Rasmidar R. Anticancer and antiproliferation activity of ant nest fraction (Myrmecodia pendens) on human tongue cancer cells SP-C1. J Dentomaxillofac Sci 2014;13:1-6.

4. Susanti HE. In vitro xanthine oxidase inhibition activity of the sarang semut (Myrmecodia tuberosa (non Jack) B1.) ethanol extract. Pharmaciana 2014;4:15-22.

5. Hamsar MN, Mizaton H. Potential of ant nest plants as an alternative cancer treatment. J Pharm Res 2012;5:3063-6.

6. Zwenger S, Basu M. Plant terpenoid: Application and future potentials. Biotecnol Mol Biol Rev 2008;3:1-7.

7. Turkmen N, Sari F, Velioglu YS. Effects of extraction solvents on concentration and antioxidant activity of black and black mate tea polyphenols determined by ferrous tartrate and folin ciocalteu methods. Food Chem 2006;99:835-41.

8. Rebey IB, Bourgou S, Debez IB, Karoui I, Sellami IH, Msaada K. Effects of extraction solvents and provenances on phenolic contents and antioxidant activities of cumin (Cuminum cyminum L.) seeds. Food Bioprocess Technol 2012;5:2827-36.

9. Cheok C, Chin N, Yusof Y, Law C. Extraction of total phenolic content from Garcinia mangostana Linn. hull. I. effects of solvents and UV Vis spectrophotometer absorbance method. Food Bioprocess Technol 2012;5:2928-33

10. Do QD, Angkawijaya AE, Tran-Nguyen PL, Huynh LH, Soetaredjo FE, Ismadji $\mathrm{S}$, et al. Effect of extraction solvent on total phenol content, total flavonoid content, and antioxidant activity of Limnophila aromatica. J Food Drug Anal 2014;22:296-302.

11. Koch S, Hufnagel M, Theilacker C, Huebner J. Enterococcal infections: Host response, therapeutic, and prophylactic possibilities. Vaccine 2004; $22: 822-30$

12. Ricucci D, Siqueira JF Jr. Biofilms and apical periodontitis: Study of prevalence and association with clinical and histopathologic findings. J Endod 2010;36:1277-88.

13. Jett BD, Huycke MM, Gilmore MS. Virulence of enterococci. Clin Microbiol Rev 1994;7:462-78.

14. Thurlow LR, Thomas VC, Hancock LE. Capsular polysaccharide production in Enterococcus faecalis and contribution of $\mathrm{CpsF}$ to capsule serospecificity. J Bacteriol 2009;191:6203-10.

15. Pinheiro ET, Penas PP, Endo M, Gomes BP, Mayer MP. Capsule locus polymorphism among distinct lineages of Enterococcus faecalis isolated from canals of root-filled teeth with periapical lesions. J Endod 2012;38:58-61.

16. Hancock LE, Gilmore MS. The capsular polysaccharide of Enterococcus faecalis and its relationship to other polysaccharides in the cell wall. Proc Natl Acad Sci U S A 2002;99:1574-9.

17. McBride SM, Fischetti VA, Leblanc DJ, Moellering RC Jr., Gilmore MS. Genetic diversity among Enterococcus faecalis. PLoS One 2007;2:e582.

18. Hancock LE, Shepard BD, Gilmore MS. Molecular analysis of the Enterococcus faecalis serotype 2 polysaccharide determinant. J Bacteriol 2003;185:4393-401.

19. Bachtiar EW, Bachtiar BM, Dewiyani S, Surono Akbar SM. Enterococcus faecalis with capsule polysaccharides Type 2 and biofilmforming capacity in Indonesians requiring endodontic treatment. J Investig Clin Dent 2015;6:197-205.

20. Thurlow L, Thomas V, Hancock SF. Enterococcus faecalis capsular polysaccharide serotype $\mathrm{C}$ dan $\mathrm{D}$ and their contribution to host innate immune evation. Infect Immun 2009;77:5551-7.

21. Engida AM, Kasim NS, Tsigie YA, Ismadji S, Huynh LH, Ju YH. Extraction, identification and quantitative HPLC analysis of flavonoids from sarang semut (Myrmecodia pendan). Ind Crops Prod
2013;41:392-6.

22. Daglia M. Polyphenols as antimicrobial agents. Curr Opin Biotechnol 2012;23:174-81.

23. Quideau S, Deffieux D, Douat-Casassus C, Pouysegu L. Plant polyphenols: Chemical properties, biological activities, and synthesis. Angew Chem Int Ed Engl 2011;50:586-621.

24. European Society of Endodontology. Quality guidelines for endodontic treatment: Consensus report of the European Society of Endodontology. Int Endod J 2006;39:921-30.

25. Haapasalo M, Shen Y, Qian W, Gao Y. Irrigation in endodontics. Dent Clin North Am 2010;54:291-312.

26. Nisar B, Rubab SA, Laila S. Comparison of medicinally important natural products versus synthetic drugs a short commentary. Nat Prod Chem Res 2018;6:2.

27. Hülsmann M, Hahn W. Complications during root canal irrigation-literature review and case reports. Int Endod J 2000;33:186-93.

28. Razak M, Yong P, Shah Z, Abdullah L, Yee S, Yaw I. The effects of varying solvent polarity on extraction yield of Orthosiphon stamineus leaves. J Appl Sci 2012;12:1207-10.

29. Gil MI, Tomás-Barberán FA, Hess-Pierce B, Kader AA. Antioxidant capacities, phenolic compounds, carotenoids, and Vitamin C contents of nectarine, peach, and plum cultivars from California. J Agric Food Chem 2002;50:4976-82

30. Devi P, Murugan S, Suja S, Selvi S, Chinnaswamy P, Vijayanand E. Antibacterial, in vitro lipid per oxidation and phytochemical observation on Achyranthes bidentata Blume. Pak J Nutr 2007;6:447-51.

31. Ehsan BR. Antimicrobial activity of the ethanolic extract of Bryonopsis laciniosa leaf, stem, fruit and seed. Afr J Biotechnol 2009;8:3565-7.

32. Bakht J, Ali H, Khan M, Islam A. Antimicrobial activities of different solvents extracted samples of Linum usitatissimum by disc diffusion method. Afr J Biotechnol 2011;10:19825-35.

33. Fitriadi F, Kurnia D, Satari M. Antibacterial activity of ethyl acetate fraction from methanolic extracts of ant-plant tubers towards Streptococcus sanguis ATCC 10566. Padjadjaran J Dent 2018:30:189-92.

34. Kurnia D, Sumiarsa D, Dharsono D, Satari M. Bioactive compounds isolated from Indonesian epiphytic plant of sarang semut and their antibacterial activity against pathogenic oral bacteria. Nat Prod Commun 2017;12:1201-4.

35. Brooks G, Carroll K, Butel J, Jawetz MS. Melnick and Adelberg's Medical Microbiology. 24 $4^{\text {th }}$ ed. New York: McGraw-Hill; 2007.

36. Andrews J. Determination of minimum inhibitory concentrations. J Antibact Chemother 2001;48:5-16.

37. Kagan IA, Flythe MD. Thin-layer chromatographic (TLC) separations and bioassays of plant extracts to identify antimicrobial compounds. J Vis Exp 2014;85:1-8.

38. Hendra R, Ahmad S, Sukari A, Shukor MY, Oskoueian E. Flavonoid analyses and antimicrobial activity of various parts of Phaleria macrocarpa (Scheff.) Boerl fruit. Int J Mol Sci 2011;12:3422-31.

39. Moein S, Moein M. Relationship between antioxidant properties and phenolics in Zhumeria majdae. J Med Plants Res 2010;7:517-21.

40. Kanthal LK, Dey A, Satyavathi K, Bhojaraju P. GC-MS analysis of bio-active compounds in methanolic extract of Lactuca runcinata DC. Pharmacogn Res 2014;6:58-61.

41. Azalework HG, Sahabjada S, Jafri A, Arshad MD, Malik T. Phytochemical investigation, GC-MS profile and antimicrobial activity of a medicinal plant Ruta graveolens L. from ethiopia. Int J Pharm Pharm Sci 2017;9:29-34

42. Biradar R, Rachetti D. Extraction of some secondary metabolites and thin layer chromatography from different parts of Centella asiatica L. Am J Life Sci 2013;1:243-7.

43. Biranti F, Nursid M, Cahyono B. Quantitative analysis of $\beta$-Karoten and carotenoid activity test in brown algae Turbinaria decurrens. J Sains Mat 2009; 17:90-6.

44. Sari RP, Wartini N, Yoga IW. Effect of type of solvent on yield and characteristics of dye extracts from Pandanus (Pandanus tectorius). J Rekayasa Manajemen Argoindustri 2015;3:103-12. 